KONSTRUKTIVISME, Vol. 8, No. 1, Januari 2016

p-ISSN: 1979-9438, e-ISSN: 2445-2355

FKIP Universitas Islam Balitar, Blitar

Web: konstruktivisme.unisbablitar.ejournal.web.id

\title{
OPTIMALISASI UJIAN SEKOLAH PRAKTIK BERBASIS LINGKUNGAN UNTUK MENANAMKAN JIWA KEWIRAUSAHAAN PESERTA DIDIK SMP NEGERI 8 BONTANG ${ }^{1}$
}

\author{
Hj. Sukarsih \\ Kepala SMP Negeri 8 Bontang \\ JI. Ir. H. Juanda Tanjung Laut Bontang Selatan \\ Bontang, Kalimantan Timur \\ Email: arsih_sagitae@yahoo.com
}

\begin{abstract}
This study is aimed at promoting school environment to teaching practice for enterpreneurship. Home industries are promoted for teaching practice objects. The study used School Action Research whose objectives are to review and evaluate school policy. Subjects of the study were 69 students of grade IX at SMPN 8 Bontang and 18 teachers three of them are science teachers. The study was conducted in January to February 2014. The findings of the study referred to UNESCO Pillars in education: learning to know, learning to do, learning to be, and learning to live together in peace and harmony. Products of the study that is "terasi" was processed by students through discovery and problem based project learning starting from finding information (learning to know), trying to make on suervisory, making by themselves (learning to be), and sale the product with school community (learning to live together). The finding probes that PAIKEM is applicable and environment is worth for teaching sources.
\end{abstract}

Key-words: environment, education pillar, creativity, characters.

\begin{abstract}
Abstrak
Penelitian ini bertujuan menggunakan lingkungan sekolah sebagai tempat ujian sekolah praktik berbasis kewirausahaan membuat produk industri rumah tangga. Penelitian menggunakan rancangan Penelitian Tindakan Sekolah yang bertujuan mereview dan mengevaluasi kebijakan sekolah. Subjek penelitian ialah 69 siswa kelas IX SMPN 8 Bontang dan 18 guru 3 di antaranya guru IPA. Penelitian dilaksanakan pada Januari-Februari 2014. Hasil penelitian menunjukkan pilar pendidikan UNESCO: belajar mengetahui, mengerjakan, menemukan, dan berkehidupan bersama cocok untuk pembelajaran praktik berbasis lingkungan. Produk industri rumah tangga berupa terasi, dikerjakan siswa melalui teknik penemuan dan pemecahan masalah. Proses dimulai dari mencari informasi mengenai terasi (learning to know), mencoba membuat terasi atas bimbingan
\end{abstract}

\footnotetext{
1 Naskah awal artikel ini ialah makalah yang diangkat dari Best Practices implementasi kebijakan Kepala Sekolah di SMPN 8 Bontang dalam mengelola sekolah. Makalah disajikan sebagai persyaratan mengikuti lomba pemilihan Kepala Sekolah Berprestasi se Kalimantan Timur pada Maret 2014 atas prakarsa kantor Depdiknas Provinsi Kalimantan Timur, Samarinda.
} 
(learning to do), membuat sendiri terasi sampai bisa (learning to be), dan memasarkan terasi melalui bazar sekolah (learning to live together). Temuannini menunjukkan bahwa PAIKEM cocok dengan model pembelajarn berbasis lingkungan sekolah.

Key-words: lingkungan, pilar pendidikan, karakter.

Pendidikan di Indonesia dianggap kurang menghasilkan lulusan yang memiliki kemampuan berpikir, kurang kreatif, dan kurang kritis. Salah satu penyebabnya ialah umumnya guru tidak kreatif dalam menyajikan materi karena terpaku pada model mengajar berbasis buku teks. Perubahan kurikulum berbasis kompetensi, KTSP dan Kurikulum berbasis learning outcomes yang disebut Kurikulum 2013 (K-13) bertujuan mendorong daya nalar tersebut. Cara yang digunakan di antaranya ialah mendorong guru menerapkan metode belajar yang berpusat pada siswa. Bebera metode yang digunakan ialah: metode proyek, pemecahan masalah, belajar berbasis lingkungan, diskusi, belajar kelompok, PAKEM, PAIKEM, dll.

Model-model pembelajaran tersebut hakikatnya proses belajar tidak hanya terpaku didalam dinding kelas. Belajar juga bisa diperoleh dari lingkungan, teman sekelas, teknologi IT, masyarakat, dan keadaan sekitar. Untuk itu, guru dan siswa dituntut untuk kreatif dan inovatif dalam memanfaatkan sumber-sumber belajar selain buku teks. Latar belakang tersebut telah mendorong peneliti untuk melakukan pembelajaran Praktik Berbasis Lingkungan di SMPN 8 Bontang. Hasilnya ialah Ujian Praktik Berbasis Lingkungan.

Secara teoritis, Ujian Praktik Berbasis Lingkungan dilandasi oleh metode pembelajaran PAIKEM dan koridor pendidikan yang dikemukakan UNESCO. Tujuannya ialah proses belajar harus mendorong guru untuk menciptakan metode belajar yang mengajar siswa aktif, inovatif, kreatif, dan mandiri. Landasan belajar tersebut menjadi tuntutan Kurikulum 2013 dengan menerapkan metode discovery, inquiry, problem solving, project, dll. Hal itu sejalan dengan koridor yang ditetapkan UNESCO, yaitu: learning to know, learning to do, learning to be, dan learning to live together in peace and harmony.

Belajar berbasis lingkungan di SMK dilaksanakan di Unit Produksi yang disiapkan sekolah. Pada sekolah umum misalnya SMP, Unit Produksi bisa diganti dengan Ujian praktik sekolah. Penelitian ini berawal dari upaya mendorong guru dan siswa di SMPN 8 Bontang agar mengoptimalkan ujian praktik sekolah. Pengalaman terbaik (best practices) tersebut peneliti lakukan dengan rancangan Penelitian Tindakan Sekolah (PTS) dengan melibatkan siswa kelas IX dan seluruh guru bidang studi yang mengajar di kelas IX. Hasil kegiatan best practices peneliti susun menjadi makalah. Adapun secara mendalam yang menjelaskan proses pelaksanaan penelitian peneliti susun ulang dalam bentuk yang lebih formal untuk peneliti jadikan artikel yang dipublikasi dalam jurnal ilmiah.

Dengan diterapkannya KTSP, maka pendekatan pembelajaran yang sebelumnya lebih banyak didominasi oleh peran guru (teacher centered) diperbaharui dengan sistem pembelajaran yang berpusat pada 
siswa (student centered). Dengan memanfaatkan lingkungan sekolah sebagai sumber belajar maka implementasi pembelajaran akan memungkinkan siswa bisa mengembangkan kreativitas, motivasi dan partisipasinya dalam pembelajaran. Guru harus mampu menghadapkan siswa dengan dunia nyata sesuai dengan yang dialaminya sehari-hari. Dari hasil pengamatan dan pengalaman peneliti pada awal menjadi Kepala SMPN 8 Bontang, guru masih jarang memanfaatkan lingkungan sebagai sumber belajar walaupun materi yang disajikan berkaitan dengan lingkungan. Begitu pula kegiatan dalam Ujian Sekolah Praktik, masih belum dimanfaatkan untuk mengoptimalkan potensi peserta didik termasuk belum dapat menanamkan jiwa kewirausahaan.

Berdasarkan latar belakang dan permasalahan di atas, maka peneliti menetapkan strategi pemecahan masalah sebagai berikut: (a) repersepsi dengan mengubah pola pikir guru dalam hal strategi pembelajaran yang sesuai dengan prinsip: (1) learning to know; (2) learning to do; (3) learning to be; dan (4) learning to live together; (b) rekonstruksi dengan memanfaatkan lingkungan sebagai sumber belajar; (c) reorientasi dengan memanfaatkan ujian sekolah praktik berbasis lingkungan sebagai sarana untuk menanamkan jiwa kewirausahaan peserta didik.

\section{Identifikasi Masalah}

Seperti kita ketahui bersama, salah satu hal yang menjadi cerminan atas ketidakberhasilan proses pendidikan, setidaknya ini adalah anggapan masyarakat, adalah tidak terserapnya lulusan sekolah dalam dunia pekerjaan. Masyarakat melihat bahwa banyak anak-anak yang lulus dari sekolah tidak mampu melakukan sesuatu yang bermanfaat bagi dirinya, apalagi untuk masyarakat. Akibatnya, banyak anak-anak yang menjadi pengangguran terdidik di masyarakat. Hal ini oleh masyarakat dianggap sebagai proses yang sia-sia.

Semua pihak perlu melakukan repersepsi dan rekonstruksi, bahkan reorientasi terhadap proses pendidikan terkait dengan kebutuhan masyarakat. Repersepsi memungkinkan tumbuhnya kesadaran atas tujuan pendidikan yang hendak dicapai secara pribadi, lokal, nasional, maupun internasional sehingga dapat mengurangi sikap negatif terhadap hasil proses pendidikan terhadap satu pihak semata. Jika semua pihak berjibaku secara bersama-sama dalam upaya membentuk kembali (rekonstruksi) bangunan pendidikan di negeri ini, maka kemungkinan pencapaian tujuan sesuai dengan kebutuhan. Reorientasi diharapkan dapat membangkitkan semangat baru dalam pengelolaan dan penyelenggaraan proses pendidikan. Dengan demikian, kita telah melakukan langkah konkrit dalam memantapkan jiwa kewirausahaan (Gugup Kismono, 2001:140).

Sekolah sudah seharusnya melakukan proses pembekalan kemampuan kewirausahaan untuk anak didiknya. Sudah waktunya sekolah menunjukkan kepada masyarakat bahwa selain memberikan bekal pengetahuan dan sikap kepada anak didik, sekolah juga memberikan keterampilan kewirausahaan kepada anak didik atau setidaknya 
menanamkan jiwa kewirausahaan kepada anak didik yang akan menjadi bekal di kehidupannya mendatang. Mereka harus dikondisikan agar:

1. Mampu membangun pemahaman dan pengetahuannya terhadap dunia di sekitarnya (learning to know).

2. Mau dan mampu berbuat untuk memperkaya pengalaman belajarnya (learning to do) dengan meningkatkan interaksi dengan lingkungannya baik lingkungan fisik, sosial, maupun budaya.

3. Mampu membangun pengetahuan dan kepercayaan dirinya (learning to be) dari hasil interaksi dengan lingkungannya itu.

4. Berkesempatan untuk berinteraksi dengan berbagai individu atau kelompok yang bervariasi (learning to live together) yang akan membentuk kepribadiannya untuk memahami kemajemukan dan melahirkan sikap-sikap positif dan toleran terhadap keanekaragaman dan perbedaan hidup. Sesuai anjuran yang dicanangkan UNESCO (Budimansyah, 2003:4).

Dari hasil pantauan penyusun selaku kepala sekolah di SMP Negeri 8 Bontang, para guru terlihat kurang kreatif dalam memberikan pengetahuan dan keterampilan kepada siswa dan belum memanfaatkan lingkungan sebagai sumber belajar sehingga prestasi siswa rendah. Para guru beralasan karena keterbatasan sarana prasarana yang dimiliki sekolah.

Maka dari itu, saya harus melakukan strategi baru untuk melakukan perubahan menjadi lebih baik dengan program optimalisasi ujian sekolah praktik berbasis lingkungan yang menyenangkan dan sekaligus untuk penanaman jiwa kewirausahaan siswa. Hal ini sesuai dengan strategi pembelajaran dengan pendekatan PAIKEM, dimana guru harus mampu menghadapkan siswa dengan dunia nyata sesuai dengan yang dialaminya sehari-hari.

Berdasarkan latar belakang tersebut di atas, maka dapat diidentifikasi masalahnya sebagai berikut:

a. Pendekatan pembelajaran yang dilakukan guru belum mengarah ke pendekatan PAIKEM yang sesuai dengan prinsip: (1) learning to know; (2) learning to do; (3) learning to be; dan (4) learning to live together, sehingga kurang mengembangkan daya nalar siswa secara optimal dan belum mampu menanamkan jiwa kewirausahaan pada peserta didik.

b. Guru belum memanfaatkan lingkungan secara optimal sebagai sumber belajar yang menyenangkan.

c. Guru belum mengembangkan strategi pembelajaran yang dapat mengeksplore potensi peserta didik.

\section{Makna Pilar Pendidikan UNESCO}

Pendidikan ialah indikator kualitas kesejahteraan suatu bangsa, karenanya arah kebijakan pendidikan suatu bangsa menunjukan arah kesejahteraan yang ingin dicapai bangsa tersebut. UNESCO telah merumuskan pedoman yang dijadikan koridor pendidikan di seluruh dunia, yang disebut dengan pilar pendidikan. Pilar tersebut ialah: learning to know, learning to do, learning to be, dan learning to live together in peace and harmony. Uraian dan contoh mengenai Pilar Pendidikan menurut 
UNESCO di bawah ini dikutip dari laman di internet dengan alamat ini: http://lp2m.web.id/pilar-pendidikan-menurut-unesco/

(diakses pada 27 Desember 2015 dan 2 Januari 2016)

Pilar yang pertama learning to know. Lerning to know maknanya belajar untuk mengetahui. Dalam proses pembelajaran aryinya siswa harus diajari memiliki pemahaman dan penalaran yang bermakna terhadap produk dan proses pendidikan (apa, bagaimana, dan mengapa) yang memadai. Belajar untuk mengetahui (learning to know) dalam prosesnya tidak sekedar mengetahui apa yang bermakna tetapi juga sekaligus mengetahui apa yang tidak bermanfaat bagi kehidupannya. Untuk mengimplementasikan "learning to know" (belajar untuk mengetahui), guru harus mampu menempatkan dirinya sebagai fasilitator. Di samping itu guru dituntut untuk dapat berperan ganda sebagai kawan berdialog bagi siswanya dalam rangka mengembangkan penguasaan pengetahuan siswa. Misalnya, siswa memahami secara bermakna fakta, konsep, prinsip, hukum, teori, model, ide, hubungan antar ide tersebut dan alasan yang mendasarinya, dan menggunakan idea itu untuk menjelaskan dan memprediksi proses-proses berikutnya.

Pilar kedua learning to do. Learning to do artinya kemampuan melakukan sesuatu. Dalam proses belajar artinya siswa dilatih memiliki keterampilan dan dapat melaksanakan proses pembelajaran yang memadai untuk memacu peningkatan perkembangan intelektualnya. Pendidikan juga merupakan proses belajar untuk bisa melakukan sesuatu (learning to do). Proses belajar menghasilkan perubahan dalam ranah kognitif, peningkatan kompetensi, serta pemilihan dan penerimaan secara sadar terhadap nilai, sikap, penghargaan, perasaan, serta kemauan untuk berbuat atau merespon suatu stimulus. Pendidikan membekali manusia tidak sekedar untuk mengetahui, tetapi lebih jauh untuk terampil berbuat atau mengerjakan sesuatu sehingga menghasilkan sesuatu yang bermakna bagi kehidupan.

Sekolah sebagai wadah masyarakat belajar seyogjanya memfasilitasi siswanya untuk mengaktualisasikan keterampilan yang dimiliki, serta bakat dan minatnya agar "learning to do" (belajar untuk melakukan sesuatu) dapat terrealisasi. Walau sesungguhnya bakat dan minat anak dipengaruhi faktor keturunan namun tumbuh dan berkembangnya bakat dan minat juga bergantung pada lingkungan. Seperti kita ketahui bersama bahwa keterampilan merupakan sarana untuk menopang kehidupan seseorang bahkan keterampilan lebih dominan daripada penguasaan pengetahuan semata

Pilar ketiga learning to be. Leming to be maknanya menjadi diri sendiri. Dalam pembelajaran artinya siswa diajari untuk menghargai, mengapresiasi nilai-nilai dan keindahan suatu produk dan proses pendidikan, ditunjukkan dengan sikap senang belajar, bekerja keras, ulet, sabar, disiplin, jujur, serta mempunyai motif berprestasi yang tinggi dan rasa percaya diri. Aspek-aspek di atas mendukung usaha siswa meningkatkan kecerdasan dan mengembangkan keterampilan intelektual dirinya secara berkelanjutan. Penguasaan pengetahuan dan keterampilan 
merupakan bagian dari proses menjadi diri sendiri (learning to be). Hali ini erat sekali kaitannya dengan bakat, minat, perkembangan fisik, kejiwaan, tipologi pribadi anak serta kondisi lingkungannya. Misal: bagi siswa yang agresif, akan menemukan jati dirinya bila diberi kesempatan cukup luas untuk berkreasi. Dan sebaliknya bagi siswa yang pasif, peran guru sebagai kompas penunjuk arah sekaligus menjadi fasilitator sangat diperlukan untuk menumbuhkembangkan potensi diri siswa secara utuh dan maksimal. Menjadi diri sendiri diartikan sebagai proses pemahaman terhadap kebutuhan dan jati diri. Belajar berperilaku sesuai dengan norma dan kaidah yang berlaku di masyarakat, belajar menjadi orang yang berhasil, sesungguhnya merupakan proses pencapaian aktualisasi diri.

Pilar keempat learning to live together in peace and harmony. Learning to live together in peace and harmony maknanya belajar hidup bersama dalam kedamaian, rukun, harmonis dan saling menghargai. Dalam proses belajar artinya siswa diajari dan dilatih bersosialisasi dan berkomunikasi dalam proses pendidikan, melalui bekerja atau belajar bersama atau dalam kelas, saling menghargai pendapat orang lain, menerima pendapat yang berbeda, belajar mengemukakan pendapat dan atau bersedia "sharing ideas" dengan orang lain dalam kegiatan pembelajaran atau bidang lainnya. Pada pilar keempat ini, kebiasaan hidup bersama, saling menghargai, terbuka, memberi dan menerima perlu dikembangkan disekolah. Kondisi seperti memungkinkan tumbuhnya sikap saling pengertian antar ras, suku, dan agama dan kelak menjadi bekal untuk berperan dalam lingkungan berada, mampu menempatkan diri sesuai dengan perannya, dan bekal dalam bersosialisasi di masyarakat (learning to live together).

\section{METODE}

Penelitian ini menggunakan rancangan Penelitian Tindakan Sekolah (PTS) karena cakupannya guru dan siswa dan pelaksanaan tindakan terjadi tidak hanya di ruang kelas tetapi juga di lingkungan sekolah dan masyarakat. Penelitian dilakukan selama dua bulan pada Januari dan Februari 2014. Subjek yang dilibatkan ialah siswa kelas IX SMPN 8 Bontang sebanyak tiga kelas dengan jumlah 69 siswa dan 18 guru yang 3 di antaranya guru IPA. Sebelum melakukan tindakan, peneliti mengidentifikasi masalah dengan cara diskusi dengan guru dan siswa. Diskusi menghasilkan strategi pemecahan masalah. Alternatif strategi pemecahan masalah yang dipilih sebagai berikut:

a. Memanfaatkan lingkungan sebagai sumber belajar.

b. Memanfaatkan ujian sekolah praktik sebagai sarana untuk meningkatkan keberdayaan peserta didik.

c. Memanfaatkan sumber belajar untuk memberdayakan peserta didik yang salah satunya adalah penanaman jiwa kewirausahaan.

Adapun bentuk tindakan dalam tahapan operasional pelaksanaannya adalah: (1) menyadarkan guru-guru akan pentingnya strategi pembelajaran dengan sharing melalui percakapan pribadi, berdiskusi dalam rapat sekolah, dan atau melalui MGMP rumpun mata 
pelajaran, (2) membentuk kembali kebiasaan yang mengaktifkan proses belajar mengajar dengan memanfaatkan lingkungan sebagai sumber belajar, (3) memberi kesempatan kepada guru untuk mengatur ulang orientasi strategi pembelajarannya sehingga dapat melakukan inovasi dalam memberdayakan peserta didik, sesuai prinsip belajar: (a) learning to know, (b) learning to do, (c) learning to be, dan (d) learning to live together dengan pemberian contoh melalui kegiatan ujian sekolah praktik.

Salah satu bukti dari berdayanya peserta didik adalah munculnya jiwa kewirausahaan dalam dirinya. Agar muncul jiwa kewirausahaan, peserta didik perlu diajari bagaimana supaya tahu, bagaimana bisa berbuat, bagaimana menjadi percaya diri, dan bagaimana agar bisa hidup di masyarakat. Sebagai tahap pembelajaran dapat melalui ujian sekolah praktik berbasis lingkungan. Jika di SMK melalui unit produksi, maka di SMP bisa melalui ujian sekolah praktik.

Bentuk ujian praktik yang peneliti berikan ialah membuat beberapa jenis produk oleh siswa sendiri. Produk dibagi ke dalam dua katagori: produk wajib berupa membuat terasi dari bahan udang atau ikan oleh siswa sendiri, dan produk pilihan berupa: membuat tape singkong, tape beras, sirup, tempe, dan abon udang. Tahap pertama, peneliti memberi penjelasan dan bekerja sama dengan guru kelas mata pelajaran biologi dan IPA peneliti memberi arahan tentang produk-produk tersebut. Tahap kedua, peneliti dan guru kelas yang ditunjuk menghubungi pengusaha terasi di wilayah sekitar sekolah untuk menjelaskan kehadiran siswa untuk dibimbing mengenai pembuatan terasi. Tahap ketiga, siswa terjun ke lapangan melakukan observasi, menerima bimbingan pembuatan terasi, praktik membuat terasi atas bimbingan, dan membuat terasi sendiri baik di rumah maupun di tempat pembuatan tereasi yang dipilih. Tahap keempat, siswa membuat pameran produk di sekolah untuk menjual hasil ujian praktik dan peneliti beserta seluruh guru dan siswa lain mengikuti bazaar tersebut.

\section{HASIL DAN BAHASAN}

\section{Alasan Pemilihan Strategi Pemecahan Masalah}

Ujian Sekolah Praktik berbasis lingkungan merupakan aplikasi dari pendekatan Pembelajaran Aktif, Inovatif, Kreatif, Efektif dan Menyenangkan (PAIKEM) yaitu pembelajaran dengan memanfaatkan lingkungan sebagai sumber belajar. Peserta didik harus diberdayakan agar:

a. Mampu membangun pemahaman dan pengetahuannya terhadap dunia di sekitarnya (learning to know).

b. Mau dan mampu berbuat untuk memperkaya pengalaman belajarnya (learning to do) dengan meningkatkan interaksi dengan lingkungannya baik lingkungan fisik, sosial, maupun budaya.

c. Mampu membangun pengetahuan dan kepercayaan dirinya (learning to be) dari hasil interaksi dengan lingkungannya itu.

d. Berkesempatan untuk berinteraksi dengan berbagai individu atau kelompok yang bervariasi (learning to live together) yang akan membentuk kepribadiannya untuk memahami kemajemukan dan 
Sukarsih, Hj. 2016. Optimalisasi Ujian Sekolah Praktik Berbasis

Lingkungan untuk Menanamkan Jiwa Kewirausahaan Peserta Didik SMP Negeri 8 Bontang. Konstruktivisme, 8(1): 72-95.

melahirkan sikap-sikap positif dan toleran terhadap keanekaragaman dan perbedaan hidup. Sesuai anjuran yang dicanangkan UNESCO (Budimansyah, 2003:4)

Pemanfaatan ujian sekolah praktik berbasis lingkungan sebagai sarana untuk menanamkan jiwa kewirausahaan dapat mengarahkan peserta didik pada peristiwa atau keadaan yang sebenarnya atau keadaan yang alami sehingga lebih nyata, lebih faktual dan kebenarannya lebih dapat dipertanggungjawabkan sehingga peserta didik mendapat bekal untuk dapat hidup lebih baik.

Manfaat nyata yang dapat diperoleh dengan memanfaatkan ujian sekolah praktik berbasis lingkungan ini adalah: (1) menyediakan berbagai hal yang dapat dipelajari anak; (2) memungkinkan terjadinya proses belajar yang lebih bermakna (meaningful learning); (3) memungkinkan terjadinya proses pembentukan kepribadian anak; (4) kegiatan belajar akan lebih menarik bagi anak; dan (5) menumbuhkan aktivitas belajar anak (learning aktivities), dan menanamkan jiwa kewirausahaan anak (Badru Zaman, dkk. 2005).

Seperti pengamatan dan pengalaman peneliti selama menjadi Kepala sekolah di SMP Negeri 8 Bontang, guru-guru di sekolah ini dalam memanfaatkan lingkungan sebagai sumber belajar sangat jarang termasuk dalam kegiatan ujian sekolah praktik. Guru lebih sering membuat soal ujian sekolah praktik hanya sekedar untuk menguji teori yang ada di buku paket. dan tidak ada sedikitpun menanamkan jiwa kewirausahaan. Sebagian besar guru mengaku enggan mengajak siswa belajar di luar kelas, karena alasan susah mengawasi dan keterbatasan sarana prasarana yang dimiliki sekolah. Selain itu ada guru yang menyampaikan bahwa mereka tidak bisa dan tidak tahu dalam memanfaatkan lingkungan sebagai sumber belajar.

Untuk mengatasi hal itu perlu adanya penyadaran dan pemahaman melalui sharing dengan: percakapan pribadi, diskusi kelompok pada saat rapat sekolah, dan diskusi diantara para guru rumpun mata pelajaran.

Dalam kegiatan percakapan tersebut para guru bisa membagi pengalaman dalam pemanfaatan lingkungan sebagai sumber belajar untuk mencapai hasil belajar yang optimal. Penelitian Nur Mohamad (dalam Ekowati, 2001) menunjukkan diskusi kolompok memiliki dampak yang amat positif bagi guru yang tingkat pengalamannya rendah maupun yang tingkat pengalamannya tinggi.

Bagi guru yang tingkat pengalamannya tinggi akan menjadi lebih matang dan bagi guru yang tingkat pengalamannya rendah akan menambah pengetahuan. Keunggulan diskusi kelompok melalui MGMP adalah keterlibatan guru bersifat holistik dan konprehensif dalam semua kegiatan. Dari segi lainnya guru dapat menukar pendapat, memberi saran, tanggapan dan berbagai reaksi sosial dengan teman seprofesi sebagai peluang bagi mereka untuk meningkatkan kemampuan dan pengalaman.

Pemanfaatan lingkungan dalam ujian sekolah praktik dapat berdampak positif bagi pengembangan potensi daerah melalui pendidikan. Seperti yang saya lakukan di SMP Negeri 8 Bontang. Sebagaimana 
diketahui Bontang adalah daerah industri dimana pupuk dan gas alam adalah dua produk terbesarnya. Disamping itu Bontang merupakan wilayah yang berdekatan dengan pantai dan tentunya banyak menghasilkan hasil laut seperti ikan, rumput laut, dan lain-lain. Hasil olahan yang paling terkenal adalah terasi. Terasi produk Bontang mempunyai cita rasa, bentuk, dan bahan yang berbeda dengan terasi produk daerah lain.

Sebagai bagian dari Kota Bontang, sudah selayaknya SMP Negeri 8 Bontang ikut mengembangkan program-program kewirausahaan daerahnya. Seperti halnya terasi. Budaya kewirausahaan diharapkan menjadi bagian dari etos kerja masyarakat dan bangsa Indonesia, sehingga dapat melahirkan wirausahawan-wirausahawan baru yang handal, tangguh dan mandiri. Jiwa kewirausahaan sangat baik bagi setiap individu, karena dapat menumbuhkan sikap kepemimpinan, tanggung jawab, disiplin, mampu mengendalikan diri dan waktu, peka akan keadaan di sekitarnya, serta mandiri. Karena di era globalisasi ini, manusia harus mampu mempertahankan hidupnya dengan kekuatannya sendiri.

Setiap ujian sekolah praktik, saya mewajibkan siswa kelas IX untuk membuat terasi dengan langkah-langkah sebagai berikut:

1. Menugaskan kepada siswa untuk mencari informasi tentang seputar terasi ke sumber ahli/masyarakat pembuat terasi (learning to know) dengan membawa surat tugas dari sekolah.. Siswa melakukan survei, tanya jawab, wawancara, praktik langsung membuat terasi dengan bimbingan sumber ahli. Siswa membuat catatan-catatan, rekaman, maupun foto dokumentasi.

2. Menugaskan siswa untuk membuat diagram alir proses pembuatan terasi (learning to know dan learning to do). Siswa dipersilahkan untuk berkreasi dalam membuat diagram alir semenarik mungkin (learning to be).

3. Menugaskan siswa untuk belajar membuat terasi di luar jam sekolah (learning to do dan learning to be). Siswa dipersilahkan berkreasi dalam hal tampilan dan proses (learning to be dan learning to live together).

4. Menugaskan siswa praktik membuat terasi sesuai jadwal pelaksanaan ujian sekolah praktik (learning to do)..

5. Menugaskan siswa untuk mempresentasikan hasil pembuatan terasinya. Siswa dipersilahkan berkreasi dalam hal teknik presentasi (learning to be).

6. Menugaskan siswa untuk memasarkan hasil pembuatan terasinya. Siswa dipersilahkan untuk berkreasi dalam hal teknik pemasaran dan penyajian (learning to be dan learning to live together).

\section{Hasil atau Dampak Yang Dicapai dari Strategi Yang Dipilih}

Berdasarkan pengamatan dan supervisi yang dilakukan peneliti, setelah melalui tahapan tindakan dalam mengoptimalkan ujian sekolah praktik berbasis lingkungan untuk menanamkan jiwa kewirausahaan pada peserta didik, membawa hasil/dampak sebagai berikut:

a. Guru menyadari dan memperoleh banyak manfaat dengan mengoptimalkan ujian sekolah praktik berbasis lingkungan 
diantaranya: (1) lingkungan menyediakan berbagai hal yang dapat dipelajari siswa, memperkaya wawasannya, tidak terbatas oleh empat dinding kelas dan kebenarannya lebih akurat; (2) proses pembelajaran dimungkinkan akan lebih menarik, tidak membosankan, dan menumbuhkan antusiasme siswa untuk lebih giat belajar; (3) belajar akan lebih bermakna (meaningful learning), sebab siswa dihadapkan dengan keadaan yang sebenarnya; (4) aktifitas siswa akan lebih meningkat dengan memungkinkannya menggunakan berbagai cara seperti proses mengamati, bertanya atau wawancara, membuktikan sesuatu, menguji fakta, dan sebagainya; (5) dapat dimungkinkan terjadinya pembentukan pribadi para siswa, seperti cinta akan lingkungan dan mempunyai jiwa kewirausahaan (Udin S W dkk, 2005). Dengan kata lain, optimalisasi ujian sekolah praktik berbasis lingkungan dapat lebih memberdayakan peserta didik.

b. Guru mata pelajaran lain yang tidak mengadakan ujian sekolah praktik dapat memanfaatkan proses ujian sekolah praktik untuk memberi nilai sesuai karakter mata pelajaran masing-masing. Sebagai contoh dalam ujian sekolah praktik IPA Biologi membuat terasi, prosesnya bisa digunakan untuk memberi nilai pada mata pelajaran Matematika, Bahasa Indonesia, Bahasa Inggris, Agama, dan lain sebagainya. Matematika, berkaitan dengan ukuran. Bahasa Indonesia, berkaitan dengan pembuatan laporan. Bahasa Inggris, berkaitan dengan inovasi presentasi menggunakan Bahasa Inggris. Agama, berkaitan dengan kejujuran. Fisika, berkaitan dengan kalori. PKn, berkaitan dengan kerjasama. Ekonomi, berkaitan dengan cara memasarkan. Geografi, berkaitan dengan keberadaan bahan. Sejarah, berkaitan dengan asal usul bahan.. SBK, berkaitan dengan variasi bentuk produk. TIK, berkaitan dengan model pelaporan. Olah Raga, berkaitan nilai gizi dan kesehatan.

Berdasarkan hasil pengamatan dan catatan yang dilakukan peneliti diperoleh hasil bahwa guru: (1) memanfaatkan lingkungan sebagai sumber belajar dalam kegiatan ujian sekolah praktik; memberdayakan peserta didik.

c. Menumbuhkan jiwa kewirausahaan pada peserta didik meskipun baru tingkat pengenalan pada ujian sekolah praktik.

d. Prestasi yang dicapai oleh sekolah, guru dan siswa mengalami peningkatan baik prestasi di bidang akademik maupun non akademik.

e. Ujian sekolah praktik berbasis lingkungan sebagai sumber belajar lebih memberdayakan peserta didik melalui learning to know, learning to do, learning to be, dan learning to live together.

\section{Kendala Yang Dihadapi Dalam Melaksanakan Strategi Yang Dipilih}

a. Masih ada beberapa guru yang sulit keluar dari zona nyaman sehingga masih terbelenggu dengan aktivitas lamanya termasuk dalam membuat soal ujian sekolah praktik. Kegiatan ujian praktik yang dikembangkan kelihatannya lebih ditekankan pada pemikiran 
reproduktif, menekankan pada hafalan dan mencari satu jawaban benar terhadap soal-soal yang diberikan, sehingga diperlukan bimbingan yang lebih intensif.

b. Kemampuan guru dalam memanfaatkan sumber belajar masih belum merata.

c. Perlu waktu dalam merubah paradigma beberapa guru terutama guruguru yang relatif lama mengajar dalam menuju guru yang profesional dan guru-guru yang tidak memiliki kemampuan berkewirausahaan, mereka memiliki sifat konservatif, artinya merasa senang dengan apa yang sudah rutin dikerjakan (rutinitas), sehingga apabila muncul sesuatu yang baru yang inovatif, guru tersebut agak sulit menerima apalagi menerapkannya. Sehingga mereka (guru yang relatif lama mengajar), 'agak sulit' untuk diajak maju dan berkembang. Guru-guru lama ini biasanya telah mengalami titik jenuh dalam mengajar dan merasa jenjang kenaikan karirnya tidak bisa berkembang atau stagnan (Tirto, A, 2008).

\section{Faktor-faktor pendukung}

a. SMP Negeri 8 Bontang berlokasi di areal yang cukup luas di tengahtengah perkampungan penduduk, sehingga sangat strategis dan memungkinkan dalam proses pembelajaran menggunakan dan memanfaatkan lingkungan

b. Kepala SMP Negeri 8 Bontang pernah menjadi guru di sekolah menengah kejuruan dan sekaligus menjadi pengelola unit produksi di sekolah tersebut.

c. Tidak adanya gap/kelompok di dalam guru, sehingga kebersamaan atau kekompakan guru menjadi modal utama dalam meningkatkan mutu tenaga pendidik di SMP Negeri 8 Sampang.

d. Sebagian besar guru SMP Negeri 8 Bontang berusia relatif muda sehingga lebih muda diarahkan menuju perubahan yang lebih baik.

e. SMP Negeri 8 Bontang sebagai sekolah berplat merah menjadi motivasi tersendiri bagi guru dalam meningkatkan kualitas pembelajaran yang lebih efektif dan mendukung pengembangan program-program kewirausahaan di sekolah.

\section{Alternatif Pengembangan}

Dalam penyelenggaraan ujian sekolah praktik berbasis lingkungan baik lingkungan alam maupun lingkungan sosial perlu adanya pemahaman tentang bagaimana alternatif/kemungkinan cara atau teknik pemanfaatannya. Pada dasarnya ada 2 kemungkinan, yaitu: (1) membawa peserta didik ke dalam lingkungan yang akan dipelajari dan (2) membawa lingkungan/sumber ahli di luar sekolah itu ke dalam peserta didik.

Teknik yang pertama (membawa peserta didik ke dalam lingkungan/sumber ahli di luar sekolah yang akan dipelajari) bisa dilakukan dengan menggunakan beberapa cara sebagai berikut: 
a. Karyawisata (Fieldtrip), yaitu mengunjungi lingkungan/sumber ahli di luar sekolah yang dijadikan objek studi tertentu sebagai bagian integral dari pelaksanaan kurikulum sesuai dengan kompetensi dasarnya, misalnya pergi belajar ke sumber ahli pembuat terasi, tempe, tapai, kerupuk, aneka minuman dan lain-lain.

b. Melaksanakan kunjungan ke pasar, yaitu bersama siswa mengadakan kunjungan ke pasar perkemahan dengan maksud tidak hanya sekedar untuk kegiatan cuci mata, belanja, dan sejenisnya saja tetapi lebih dari itu untuk memperkenalkan dan mempelajari lingkungan yang berkaitan dengan kewirausahaan.

c. Melakukan kegiatan survey, yaitu mengunjungi objek tertentu yang relevan dengan tujuan pembelajaran, misalnya untuk mempelajari kebiasaan jual beli manisan rumput laut dan sebagainya diantaranya melalui wawancara dengan pihak-pihak yang dianggap perlu (interview), melakukan pengamatan (observasi) atau mempelajari dokumen-dokumen yang diperlukan (studi dokumentasi).

d. Melakukan praktek kerja, yaitu para siswa diajak melakukan praktek kerja pada tempat-tempat pekerjaan yang ada di sekitar lingkungan sekolah, misalnya ke home industry terasi Bontang Kuala dan sekaligus melakukan praktik kerja membuat terasi dan lain sebagainya.

e. Mengadakan suatu proyek pelayanan kepada masyarakat, mengajak siswa mengadakan suatu proyek pelayanan kepada masyarakat, misalnya membantu dalam hal kebersihan lingkungan, kerja bakti menanam pohon di pantai terdekat dan lain sebagainya.

Teknik yang kedua (membawa lingkungan/sumber ahli di luar sekolah itu ke dalam peserta didik) bisa dilakukan dengan menggunakan beberapa cara diantaranya:

a. Mengundang sumber ahli di luar sekolah untuk berbicara soal kewirausahaan atau cara-cara menanamkan jiwa kewirausahaan kepada para siswa/warga sekolah di dalam kelas/di sekolah.

b. Mengundang pelaku usaha, dan atau tokoh masyarakat lainnya sebagai nara sumber (ressource person) untuk berbicara di depan para siswa dan warga sekolah mengenai berbagai hal yang berkaitan dengan bidang kewirausahaan.

Untuk mengundang nara sumber tersebut, sebelumnya kepala sekolah dan atau guru harus mempersiapkan terlebih dahulu siapa yang tepat dijadikan nara sumber, topik apa yang diminta untuk dibahas, kapan waktunya yang tepat, bagaimana menghubunginya dan yang terpenting juga apa saja yang harus dilakukan oleh siswa dan warga sekolah.

Agar memperoleh hasil belajar yang maksimal dalam pemanfaatan lingkungan, perlu membuat persiapan yang matang. Ada 3 langkah yang dapat guru lakukan untuk menggunakan lingkungan sebagai sumber belajar, yaitu: (1) langkah perencanaan, (2) langkah pelaksanaan, dan (3) langkah tindak lanjut (follow up). 


\section{SIMPULAN}

Dari pembahasan yang dilakukan di atas dapat ditarik simpulan sebagai berikut:

1. Optimalisasi ujian sekolah praktik berbasis lingkungan sesuai dengan prinsip learning to know, learning to do, learning to be, dan learning to live together. Model pembelajaran yang berbasis lingkungan seperti yang diterapkan pada optimalisasi ujian sekolah praktik dapat menanamkan jiwa kewirausahaan peserta didik.

2. Setelah melalui tahapan tindakan, nampak mulai membawa hasil yang cukup menggembirakan sebagai berikut: (a) guru menyadari dan memperoleh banyak manfaat dengan mengoptimalkan ujian sekolah praktik berbasis lingkungan; (b) guru mata pelajaran yang tidak mengadakan ujian sekolah praktik dapat memanfaatkan proses ujian sekolah praktik untuk memberi nilai sesuai karakter mata pelajaran masing-masing; (c) menumbuhkan jiwa kewirausahaan pada peserta didik; (d) Prestasi yang dicapai oleh sekolah, guru dan siswa mengalami peningkatan.

3. Kendala yang dihadapi dalam melaksanakan strategi yang dipilih selain belum optimalnya pelaksanaan Ujian sekolah Praktik, juga disebabkan karena sulitnya mengajak guru-guru yang memiliki sifat konservatif untuk diajak maju dan berkembang.

4. Sementara faktor pendukungnya adalah: (1) lokasi SMPN 8 Bontang yang cukup luas dan strategis; (2) tidak adanya gap di dalam guru; (3) usia guru relatif muda; (4) SMP Negeri 8 Bontang sebagai sekolah plat merah menjadi motivasi tersendiri bagi guru dalam meningkatkan kinerjanya, dan (5) Kepala sekolah pernah bertugas di sekolah kejuruan.

5. Alternatif Pengembangan dapat dilakukan melalui 2 kemungkinan, yaitu: (1) membawa peserta didik ke dalam lingkungan yang akan dipelajari dan (2) membawa lingkungan itu ke dalam peserta didik.

\section{SARAN}

a. Kepada guru-guru khususnya guru di SMP Negeri 8 Bontang, dengan dan kemampuannya untuk berubah perlu terus melakukan inovasi pembelajaran dalam rangka ikut menanamkan jiwa kewirausahaan pada peserta didik.

b. Kepada pihak sekolah dalam hal ini kepala sekolah selaku pemimpin pendidikan perlu terus melakukan inovasi pengelolaan sekolah dalam rangka mewujudkan visi dan misi sekolah. Sekolah dapat memanfaatkan forum diskusi seperti percakapan pribadi, rapat sekolah, dan MGMP serta MKKS sebagai kegiatan yang dapat memberikan inspirasi dan motivasi dalam mengoptimalkan kegiatan sekolah.

c. Kepada pengawas sekolah, dapat membantu dalam membimbing dan mengawasi guru dalam pelaksanaan tugasnya sehingga dapat meningkatkan kompetensi dan profesionalisme guru. 
Sukarsih, Hj. 2016. Optimalisasi Ujian Sekolah Praktik Berbasis

d. Kepada Dinas Pendidikan atau instansi terkait sebagai bahan masukan dalam mengambil kebijakan/keputusan sebagai upaya meningkatkan kompetensi dan profesionalisme guru termasuk meningkatkan mutu pendidikan.

\section{DAFTAR PUSTAKA}

Adi, Tirto. 2008. Menggali Potensi, Menggapai Prestasi di SMP Negeri 1 Tarik Sidoarjo. Best Practices. Tidak dipublikasikan.

Budimansyah, D. 2003. Model Pembelajaran Berbasis Portofolio Biologi. Bandung: Ganesindo.

Kismono, Gugup. 2001. Pengantar Bisnis. Jakarta. Erlangga.

Permendiknas Nomor 41 tahun 2007 tentang Standar Proses. Himpunan Peraturan Pemerintah RI di Bidang Pendidikan. Jakarta. Binatama Raya.

Winataputra, Udin S. 2005. Strategi Belajar Mengajar. Buku Materi Pokok PGSD2201. Modul 1-12. Jakarta. Universitas Terbuka.

Zaman, Badru, dkk. 2005. Media dan Sumber Belajar TK. Buku Materi Pokok PGTK 2304. Modul 1-9. Jakarta Universiats Terbuka. 
KONSTRUKTIVISME, Vol. 8, No. 1, Januari 2016

p-ISSN: 1979-9438, e-ISSN: 2445-2355

FKIP Universitas Islam Balitar, Blitar

Web: konstruktivisme.unisbablitar.ejournal.web.id

\section{LAMPIRAN FOTO KEGIATAN}

\section{LEARNING TO KNOW}

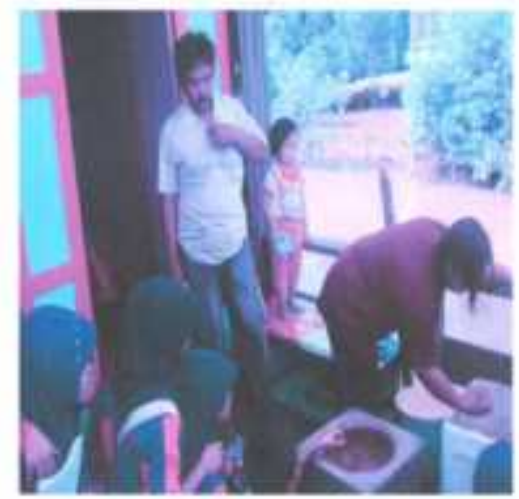

Mencari tahu bahan dasar membuat terasi dari sumber ahli

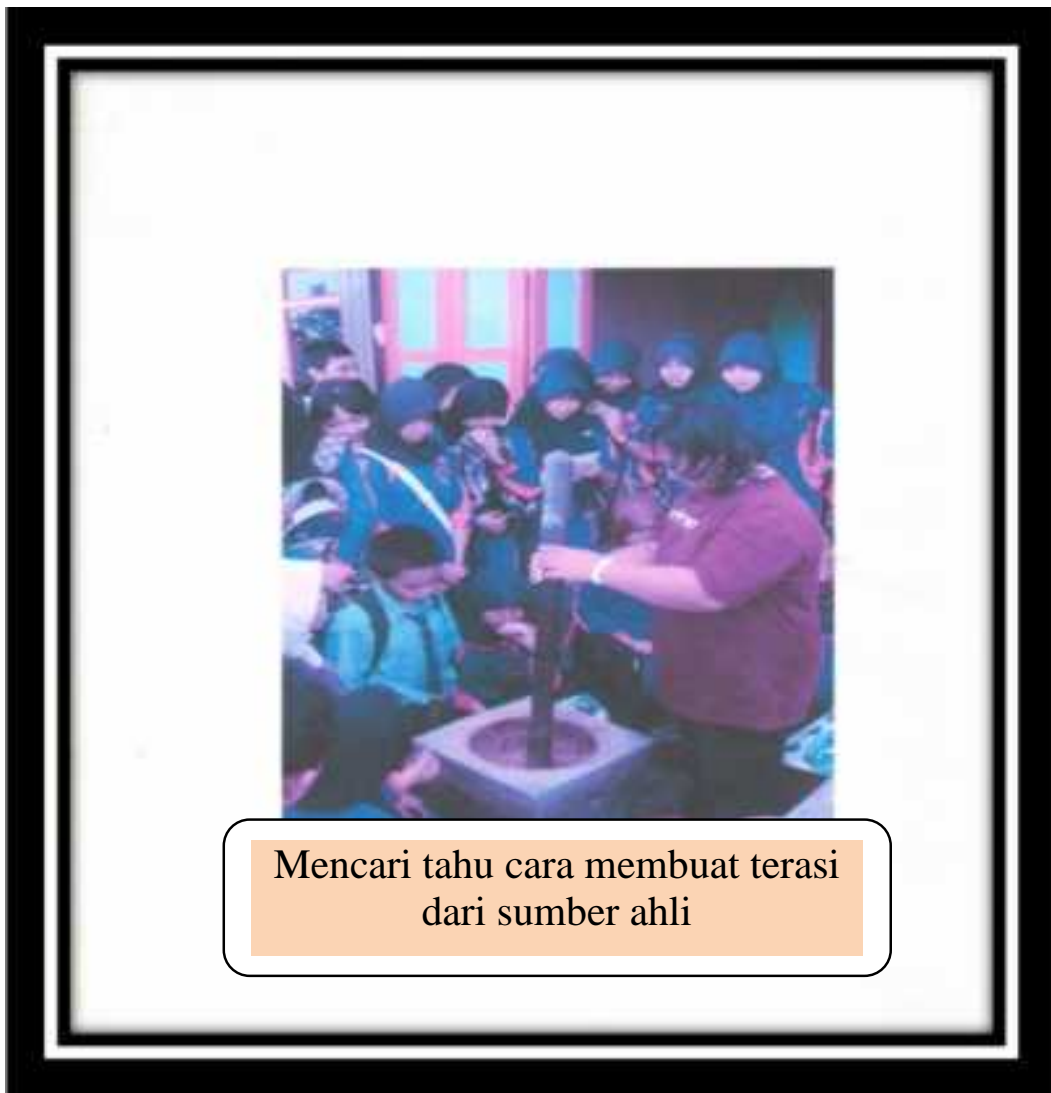


Sukarsih, Hj. 2016. Optimalisasi Ujian Sekolah Praktik Berbasis Lingkungan untuk Menanamkan Jiwa Kewirausahaan Peserta Didik SMP Negeri 8 Bontang. Konstruktivisme, 8(1): 72-95.

\section{LEARNING TO DO}

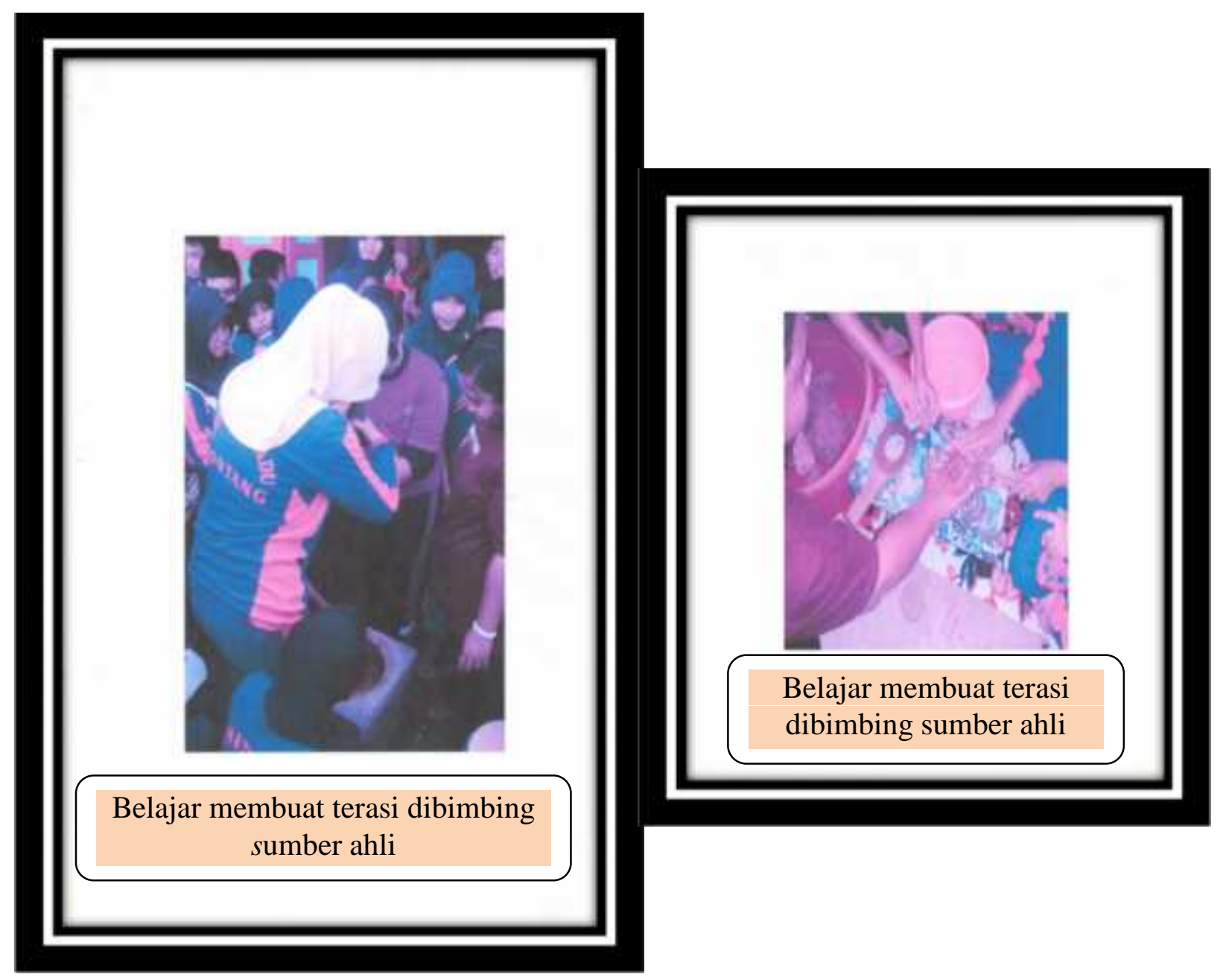


p-ISSN: 1979-9438, e-ISSN: 2445-2355

FKIP Universitas Islam Balitar, Blitar

Web: konstruktivisme.unisbablitar.ejournal.web.id
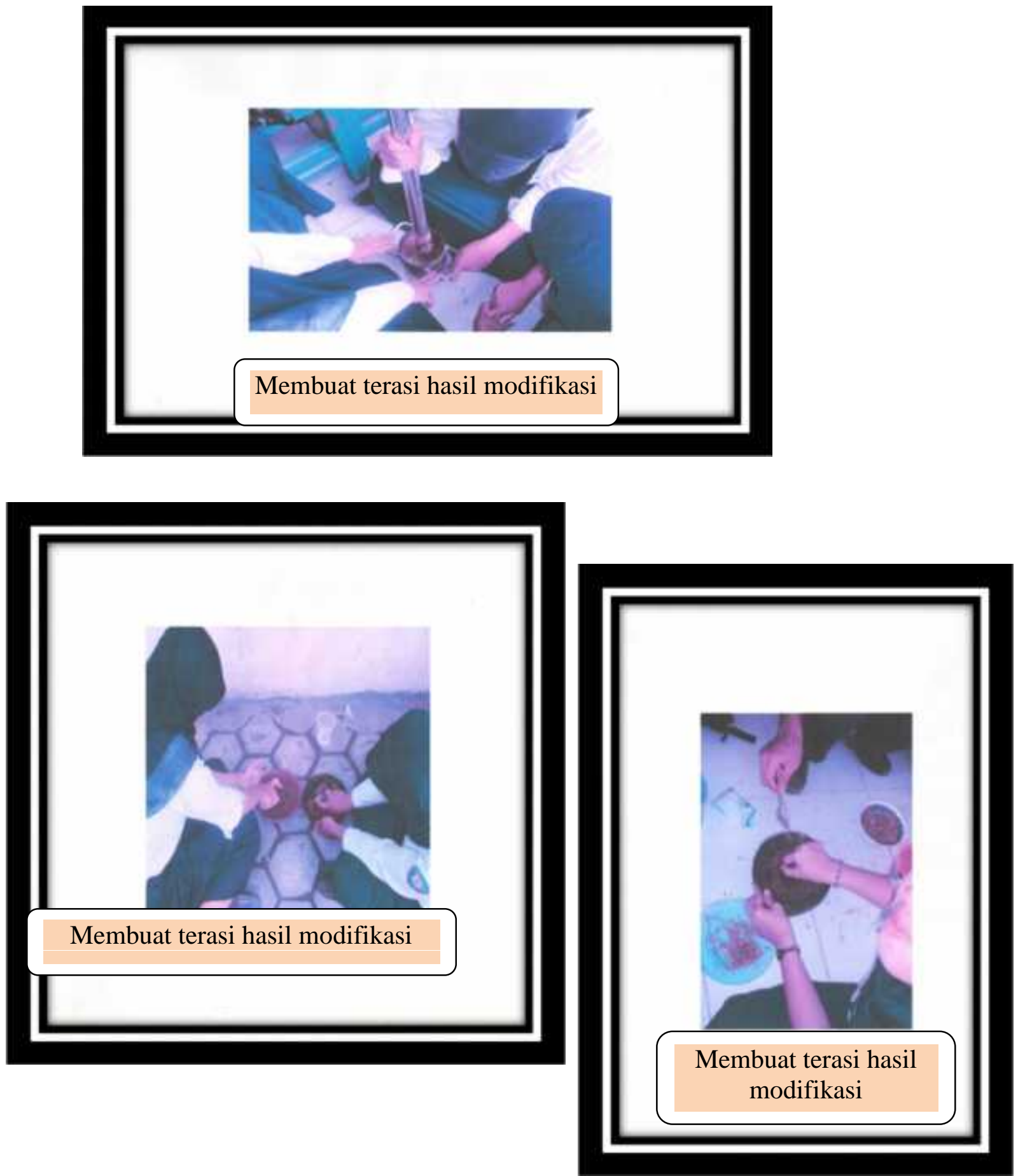
Sukarsih, Hj. 2016. Optimalisasi Ujian Sekolah Praktik Berbasis Lingkungan untuk Menanamkan Jiwa Kewirausahaan Peserta Didik SMP Negeri 8 Bontang. Konstruktivisme, 8(1): 72-95.

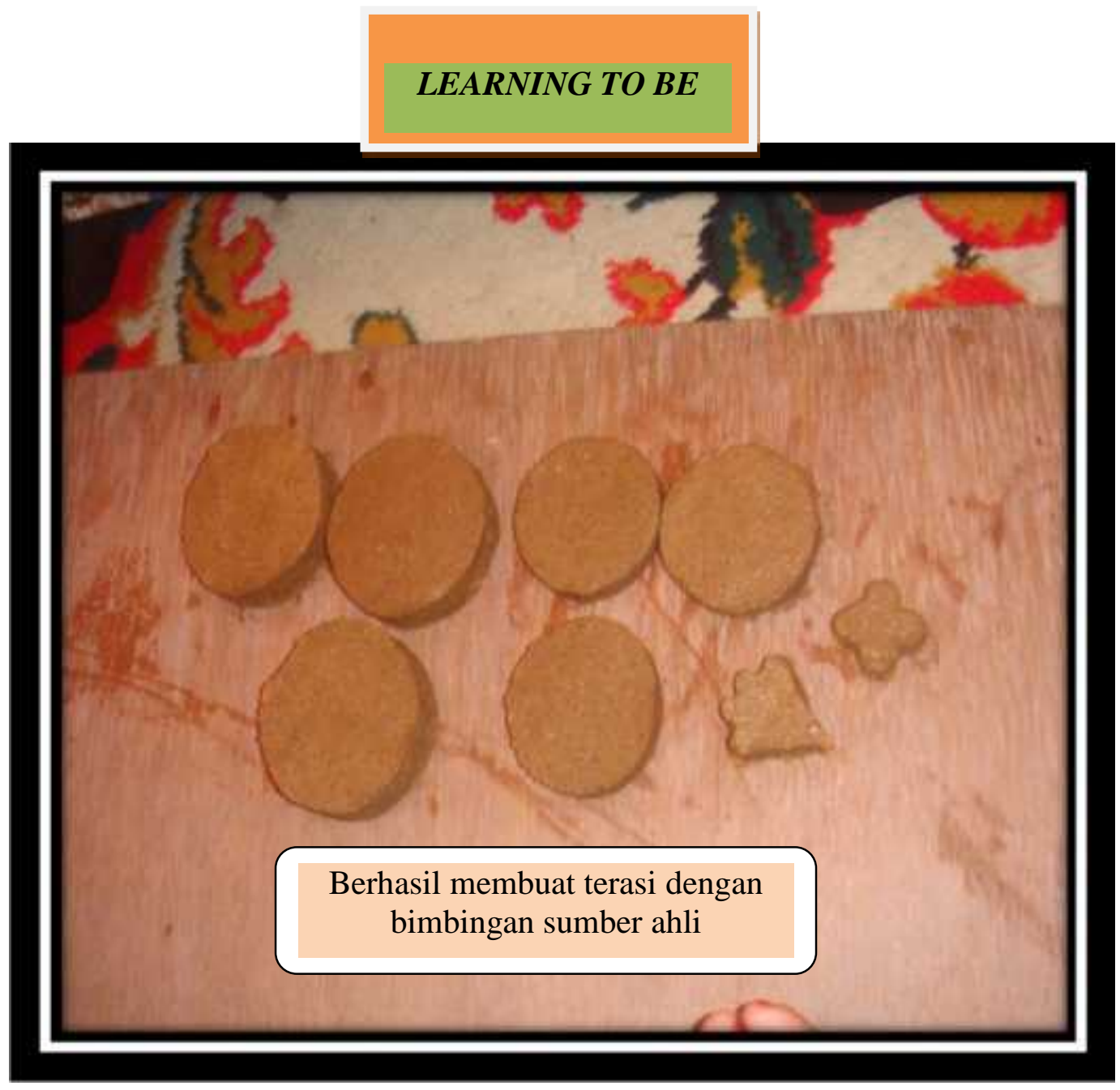




\section{LEARNING TO BE}

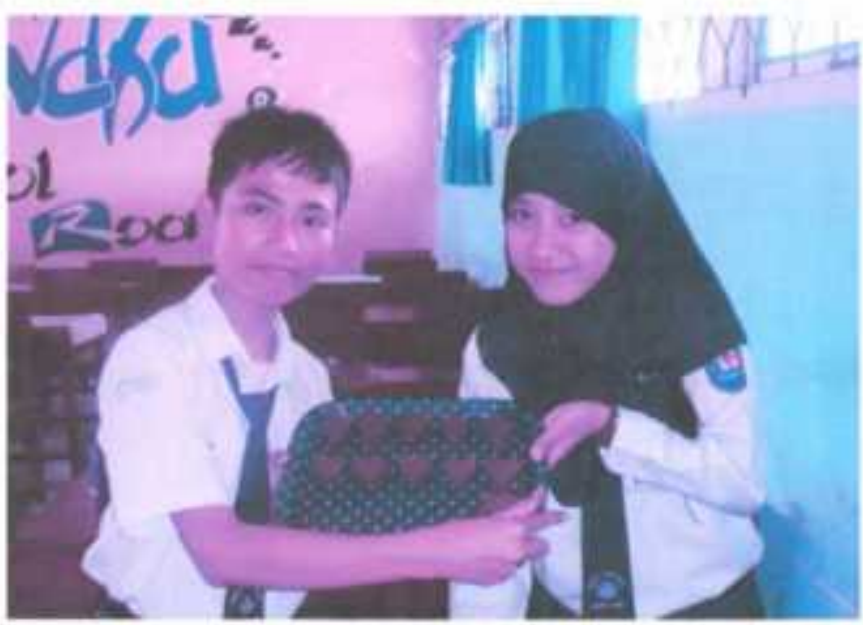

Berhasil membuat terasi sendiri 


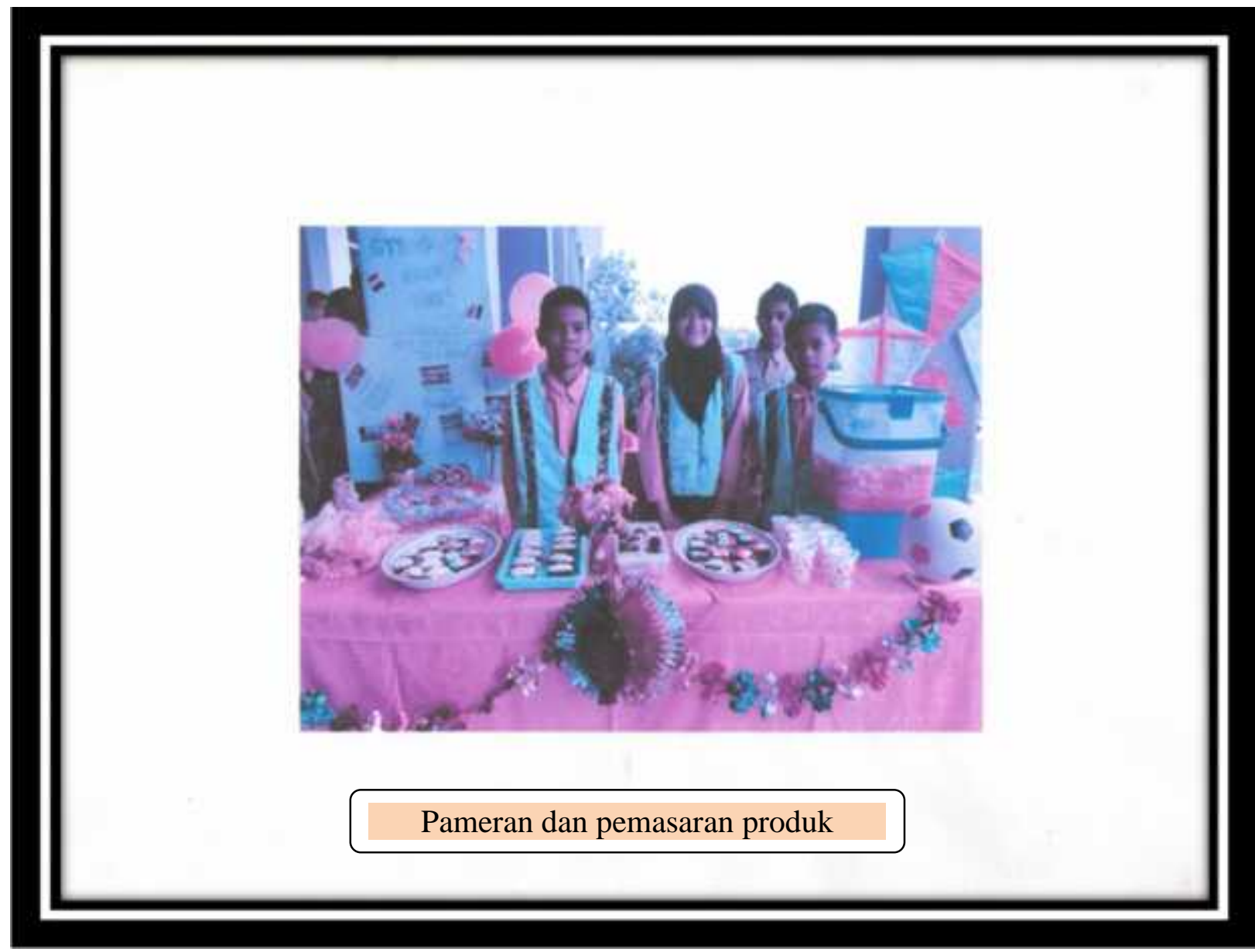


p-ISSN: 1979-9438, e-ISSN: 2445-2355

FKIP Universitas Islam Balitar, Blitar

Web: konstruktivisme.unisbablitar.ejournal.web.id

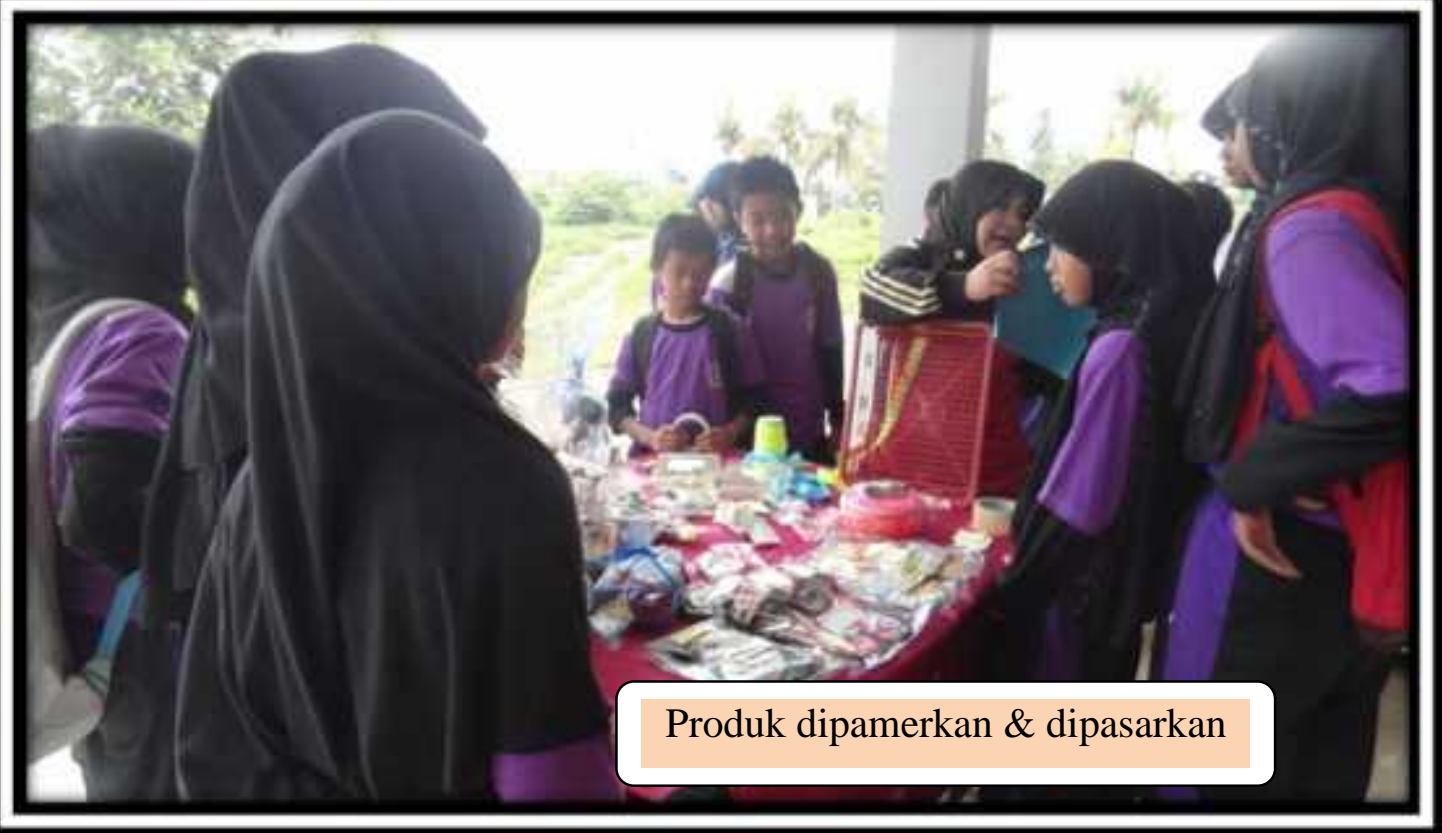


Sukarsih, Hj. 2016. Optimalisasi Ujian Sekolah Praktik Berbasis Lingkungan untuk Menanamkan Jiwa Kewirausahaan Peserta Didik SMP Negeri 8 Bontang. Konstruktivisme, 8(1): 72-95.

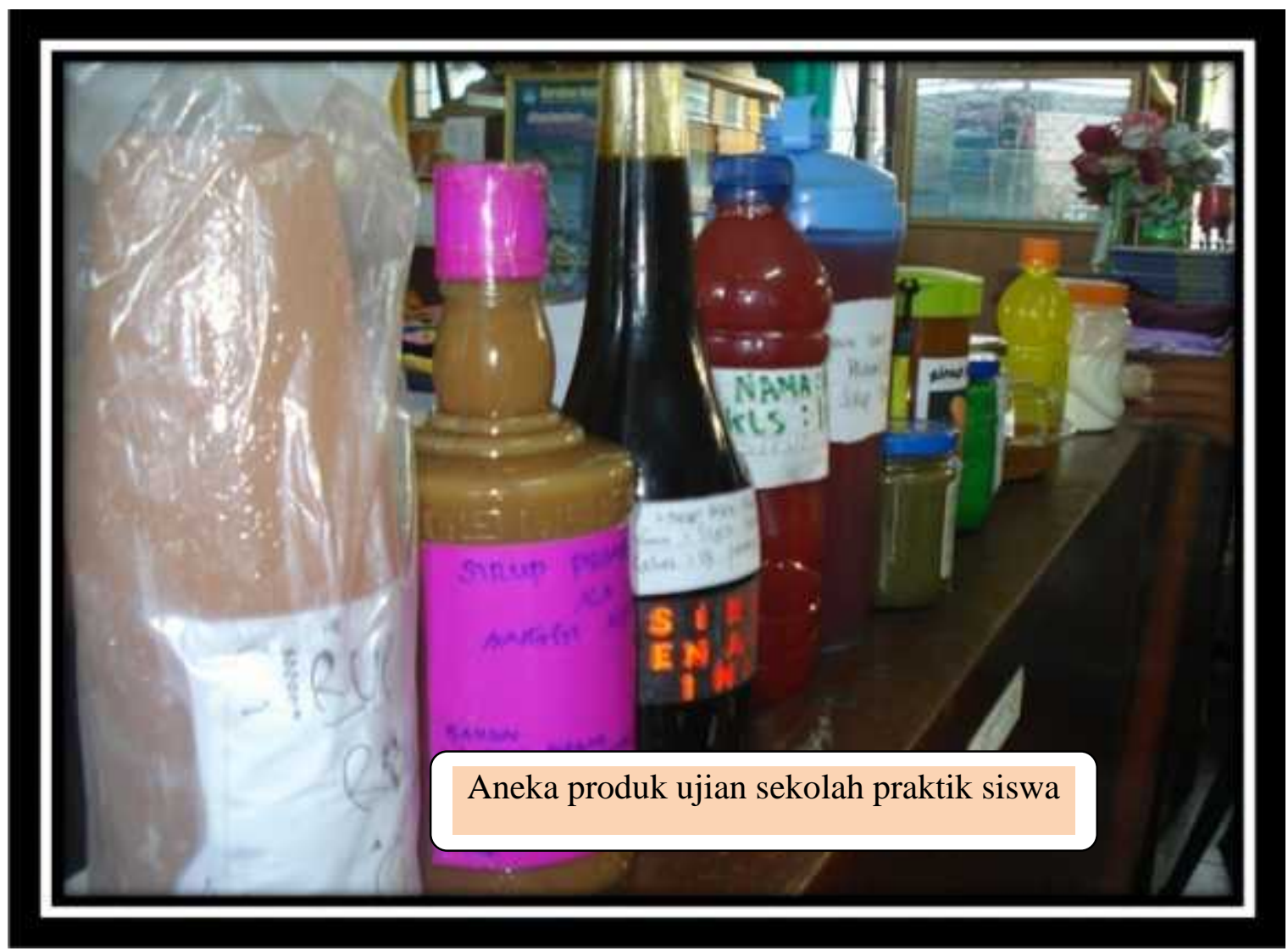


KONSTRUKTIVISME, Vol. 8, No. 1, Januari 2016

p-ISSN: 1979-9438, e-ISSN: 2445-2355

FKIP Universitas Islam Balitar, Blitar

Web: konstruktivisme.unisbablitar.ejournal.web.id

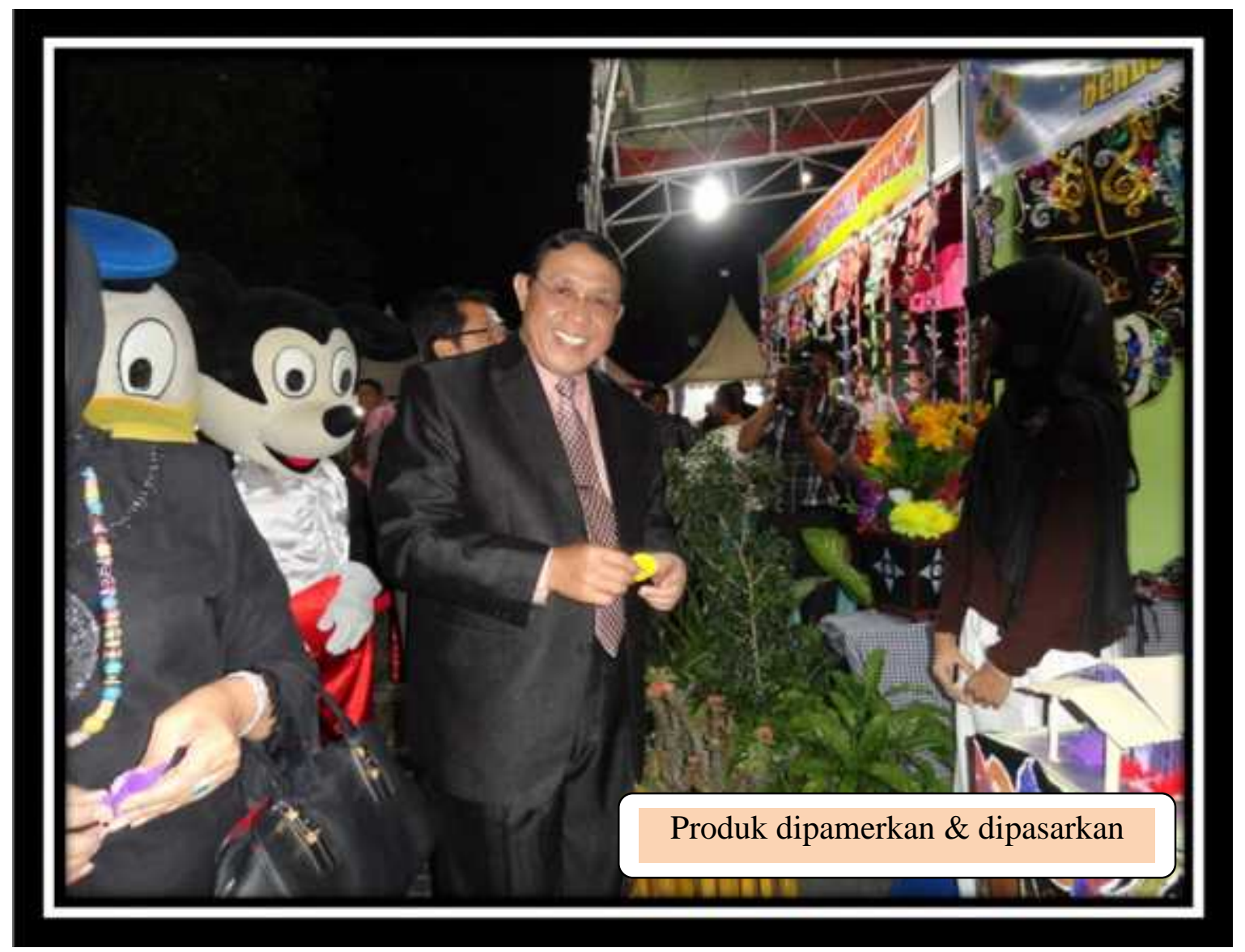


Sukarsih, Hj. 2016. Optimalisasi Ujian Sekolah Praktik Berbasis Lingkungan untuk Menanamkan Jiwa Kewirausahaan Peserta Didik SMP Negeri 8 Bontang. Konstruktivisme, 8(1): 72-95.

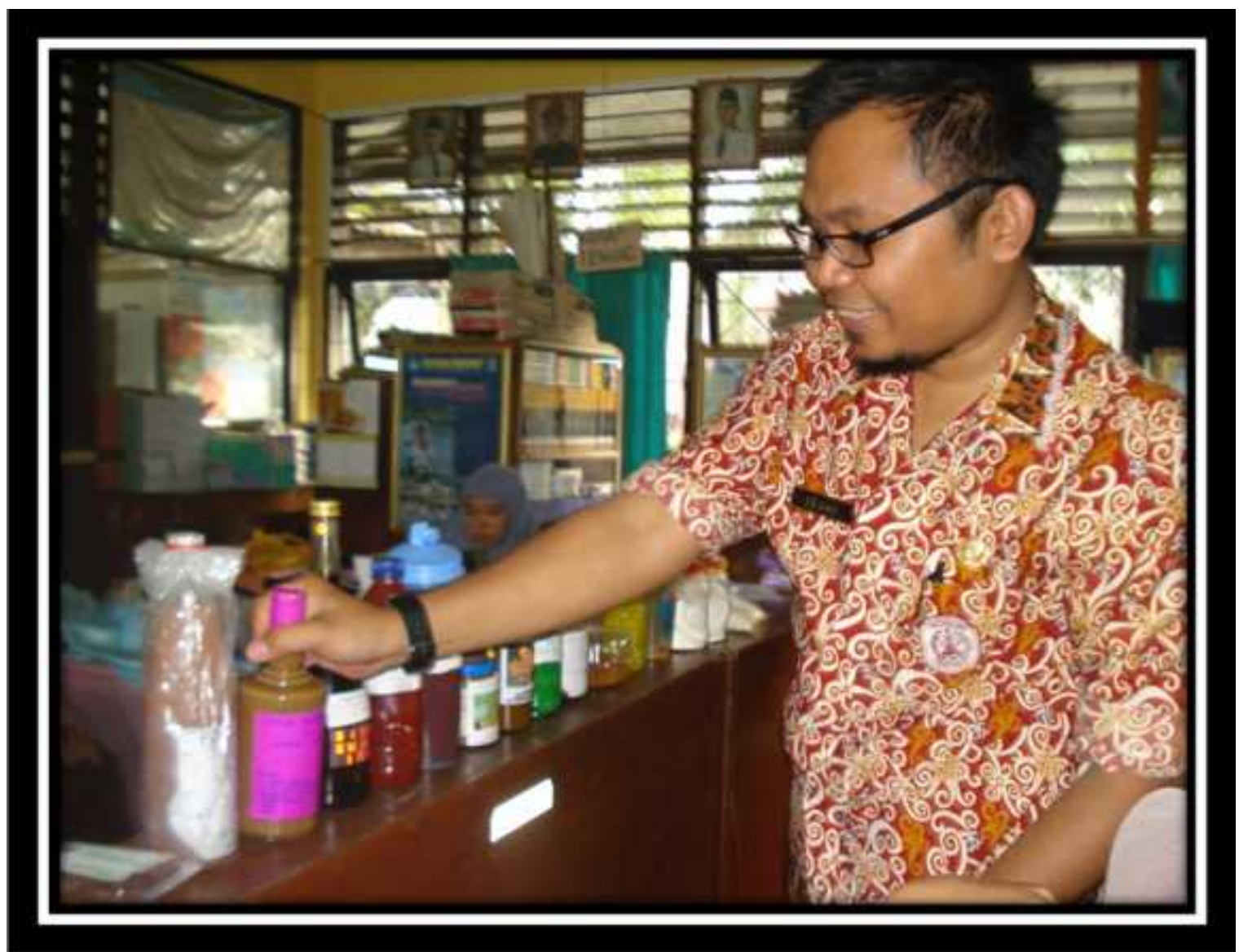

